\title{
Pengaruh promosi dan harga terhadap keputusan pembelian pada hotel berbintang tiga di kota palembang
}

\author{
Deyto Honggoriansyah ${ }^{1)}$, Pelliyezer Karo Karo ${ }^{2)}$, Mustika Permatasari ${ }^{3)}$ \\ Politeknik Pariwisata Negeri Palembang, J1. Sapta Pesona No. 10, Jakabaring 30247 Indonesia \\ 1deyto-honggo@gmail.com, 2pelliyezer@ poltekpar-palembang.ac.id, \\ ${ }^{3}$ mustika.permata1986@gmail.com
}

\begin{abstract}
Abstrak
Kota Palembang merupakan ibu kota Provinsi Sumatera Selatan yang memiliki potensi wisata yang beragam da lam menarik wisatawan. Tak bisa dipungkiri bahwa Asian Games yang digelar pada 2018 turut berkontribusi pada semakin meningkatknya jumlah akomodasi di Kota Palembang. Dengan a danya kegiatan promosi yang dilakukan oleh pengelola hotel serta penawaran harga y ang terbaik bagi konsumen maka penentuan keputusan pembelian akan semakin mudah. Penelitian ini merupakan penelitian deskriptif verifikatif dengan menggunakan metode survei eksplanatori dan teknik analisis yang digunakan adalah analisis jalur. Tujuan penelitian ini a dalah untuk mengetahui pengaruh promosi dan harga baik secara simultan maupun parsial terhadap keputusan pembelian pada tiga Hotel Bintang Tiga yaitu Hotel Santika Radial Palembang, Hotel Batiqa Pa lembang, dan Hotel Swarna Dipa. Berdasarkan hasil penelitian, diperoleh bahwa hubungan antara variabel promosi terhadap keputusan pembelian memiliki nilai 0,988 . Hubungan antar v ariabel harga terhadap keputusan pembelian memiliki nilai harga sebesar 0,756 . Hubungan promosi dan harga terhadap keputusan pembelian berda sarkan hasil penelitian ini menyatakan memiliki pen ga ruh yang signifika n terhadap keputusan pembelian.
\end{abstract}

Kata kunci: Promosi, Harga dan Keputusan Pembelian

\section{Abstract}

Palembang City is the ca pital of South Sumatra Province which has diverse tourism potential in attracting tourists. It cannot be denied that the Asian Games will be held in 2018, contributing to the increasing number of accommodations in the city of Palembang. With the promotion activities carried out by hotel managers as well as offering the best prices for consumers, the determination of purchasing decisions will be ea sier. This research is a descriptive verification study using ex planatory survey methods and the analysis technique used is path analysis. The purpose of this study was to determine the effect of promotions and prices both simultaneously and partially on purchasing decisions at three Three-StarHotels, namely Santika Radial Palembang, Batiqa Hotel Pa lembang, and Swarna Dipa Hotels. The relationship between promotion variables on purchasing decisions has a value of 0.988 . The relationship between price variables on purchasing decisions has a price value of 0.756 . The relation ship between promotion and price on purchasing decisions based on the results of this study states have a significant influence on purchasing decisions.

Key words: Promotion, Price and Purchasing Decisions

\section{PENDAHULUAN}

Pariwisata di Indonesia secara berkelanjutan berkembang menjadi suatu industri bisnis dibidang jasa yang dapat memenuhi segala kebutuhan seiring dengan bertambahnya kegiatan kepariwisataan. Terdapat berbagai macam potensi destinasi wisata di Indonesia yang dapat meningkatkan jumlah kunjungan wisatawan baik domestik maupun mancanegara. Salah satu destinasi wisata yang memiliki potensi untuk mengembangkan kegiatan pariwisatanya adalah Kota Palembang.

Kota Palembang merupakan Ibukota Provinsi Sumatera Selatan yang memiliki potensi wisata beragam dalam menarik para wisatawan, mulai dari wisata alam, budaya, kuliner serta potensi wisata olahraga. Dengan adanya wisata olahraga ini diharapkan mampu membuat Kota Palembang untuk menggali potensi pariwisata lebih berkembang.

Pada tahun 2017, Kota Palembang sudah mempersiapkan daerahnya untuk menyambut satu event internasional yang bergengsi yaitu Asian Games. Dukungan pemerintah daerah dalam melakukan 
pembenahan untuk menyambut para tamu negara yang akan hadir pada event internasional terlihat sangat jelas. Hal ini terlihat dengan ditambahnya penyediaan sarana dan fasilitas yang dibangun untuk mengakomodir kebutuhan para atlet, official committee, supporter dan delegasi dari berbagai negara yang berkunjung ke Kota Palembang.

Tingkat pertumbuhan jumlah kamar dan tingkat hunian kamar yang ada di Kota Palembang dari tahun 2016 sampai 2018 pun terlihat mengalami peningkatan secara signifikan, hal ini sesuai dengan data pada tabel 1 sebagai berikut :

\section{Tabel 1. Jumlah Kamar Per Tahun Dan Tingkat Hunian Kamar Pertahun Hotel Berbintang}

\begin{tabular}{|l|l|l|l|l|l|}
\hline No. & Tahun & $\begin{array}{l}\text { Jumlah } \\
\text { Kamar }\end{array}$ & $\begin{array}{l}\text { Tingkat } \\
\text { Hunian }\end{array}$ & Keterangan \\
\hline 1 & 2016 & 4655 & $46.80 \%$ & $\begin{array}{l}\text { Saat Asian } \\
\text { Games 2018 } \\
\text { (Ags-Sep), } \\
\text { tingkat } \\
\text { hunian } \\
\text { kamar 100\% }\end{array}$ \\
\hline 2 & 2017 & 4725 & $64.50 \%$ \\
\hline 3 & 2018 & 12000 & $55.79 \%$ \\
\hline
\end{tabular}

Sumber : Palembang Dalam Angka, BPS

Dari tabel 1, dapat dilihat adanya peningkatan dalam penambahan jumlah kamar pada tahun 2018 jika dibandingkan tahun 2017 atau 2016. Peningkatan jumlah kamar tersebut diakibatkan dengan adanya persiapan pemerintah daerah untuk kegiatan Asian Games yang akan dilangsungkan pada 2018.

Tidak dapat dipungkiri dengan adanya kegiatan Asian Games yang akan dilaksanakan pada tahun 2018, memberikan kontribusi dalam mendorong bertambahnya jumlah akomodasi yang ada di Kota Palembang. Dengan adanya kegiatan tersebut maka berpengaruh pula terhadap persaingan antara pengelola hotel dalam menarik para wisatawan untuk menginap di hotel yang dikelolanya.

Saat ini persaingan bisnis perhotelan tidak hanya dari segi fasilitas fisik saja seperti kamar, restoran, dan sebagainya namun aspek promosi juga menjadi salah satu strategi yang mampu membuat keputusan pembelian wisatawan untuk menginap di hotel. Kegiatan promosi yang dilakukan memiliki tujuan dalam memberitahukan atau menawarkan produk atau jasa pada yang bertujuan menarik calon konsumen untuk membeli atau mengkonsumsinya.

Menurut Tjiptono (2014:42), promosi merupakan metode yang terdiri atas iklan, promosi penjualan, pemasaran langsung, penjualan personal, dan relasi publik. Kegiatan promosi dapat dilakukan untuk menginformasikan produk serta fasilitas dan layanan yang ada di suatu hotel. Semakin berkembangnya ketersediaan informasi yang diberikan, maka mampu membuat konsumen mendapatkan informasi lebih banyak dalam memutuskan pembelian. Dan kegiatan promosi sangat berkaitan erat dengan keputusan pembelian para konsumen.

Selain tersedianya fasilitas dan pelayanan yang baik maka sebanding dengan harga yang ditawarkan oleh para pengusaha hotel. Harga merupakan salah satu atribut terpenting yang dievaluasi oleh para konsumennya sehingga para manager perlu memahami peran harga tersebut dalam pembentukan sikap konsumen, (Mowen dan Minor 2009:318).

Berdasarkan Gitosudarmo (2000:228) harga ialah jumlah uang tertentu yang dikeluarkan demi mendapatkan jumlah barang beserta jasa dengan jumlah tertentu. Karenanya dalam penetapan harga, setiap perusahaan harus mampu menentukan harga penjualan sesuai dengan pangsa pasar yang dituju agar penjualan produk jasa dan pangsa pasar semakin meningkat.

Dalam penelitian ini, peneliti ingin mengetahui pengaruh promosi dan harga baik secara simultan maupun parsial terhadap keputusan menginap di tiga Hotel Berbintang Tiga yaitu Santika Radial Palembang, Batiqa Hotel Palembang dan Hotel Swarna Dipa.

\section{METODOLOGI}

Penelitian ini merupakan penelitian kuantitatif dan verifikatif yang dimana dalam penelitian ini akan diuji apakah promosi dan harga berpengaruh terhadap keputusan pembelian di hotel berbintang 3 di 
Kota Palembang. Objek penelitian adalah tamu hotel yang menginap di hotel berbintang tiga di Santika Radial Palembang, Batiqa Hotel Palembang dan Swarna Dwipa Palembang.

Populasi dalam penelitian ini yaitu tamu yang menginap di Hotel Bintang Tiga dengan periode dari Bulan Agustus 2018-November 2018, dengan jumlah tamu yang menginap sebanyak 22.288 orang. Jumlah sampel yang diambil dalam penelitian ini diperoleh sebesar 393 sampel dari jumlah populasi tamu dengan pendekatan Slovin pada tingkat signifikansi 5 persen. Pengumpulan data primer menggunakan teknik sampling non probability sample melalui accidental sampling.

\section{Operasional Variabel}

Operasional variabel dibutuhkan untuk mengurai variabel menjadi sejumlah variabel operasional atau variabel empiris menunjuk langsung pada beberapa hal yang akan diukur atau diamati melalui pemberian nilai angka (kuantitatif) atau nilai mutu (kualitatif). Dalam penelitian ini terdapat dua jenis variabel yaitu variabel terikat dan variabel bebas.

Tabel 2. Operasional Variabel

\begin{tabular}{|c|c|c|}
\hline Variabel & Dimensi & Indikator \\
\hline \multirow{13}{*}{$\begin{array}{l}\text { Promosi(Promotion) } \\
\mathrm{X}_{1}\end{array}$} & \multirow[b]{2}{*}{$\begin{array}{l}\text { Periklanan } \\
\text { (Advertising) }\end{array}$} & Iklan memiliki tujuan yangjelas \\
\hline & & $\begin{array}{l}\text { Isi pesan yang ada didalam iklan memiliki daya tarik } \\
\text { tersendiri da lam memberikan informasi }\end{array}$ \\
\hline & \multirow{3}{*}{$\begin{array}{l}\text { Promosi Penjualan } \\
\text { (Sales Promotion) }\end{array}$} & $\begin{array}{l}\text { Tamu dapat melihat langsung contoh produk baik secara } \\
\text { langsung maupun melaluifoto }\end{array}$ \\
\hline & & $\begin{array}{l}\text { Adanya kupon atau potongan harga yang diberikan oleh } \\
\text { hotel }\end{array}$ \\
\hline & & Media penjualan hotel menarik \\
\hline & \multirow{3}{*}{$\begin{array}{l}\text { Pema saran Langsung } \\
\text { (Direct Marketing) }\end{array}$} & $\begin{array}{l}\text { Adanya kegiatan promosi melalui brosur maupun katalog } \\
\text { a taubrosur }\end{array}$ \\
\hline & & $\begin{array}{l}\text { Konsumen dapat memberikan tanggapan langsung terhadap } \\
\text { produk dari hotel }\end{array}$ \\
\hline & & $\begin{array}{l}\text { Kemudahan dalam pembelian kamar hotel yang efektif } \\
\text { mulai dari kemudahan pemesanan, cara pembayaran, hingga } \\
\text { pelayanan checkoutyang mudah }\end{array}$ \\
\hline & \multirow{4}{*}{$\begin{array}{l}\text { Penjualan Personal } \\
\text { (PersonalSelling) }\end{array}$} & $\begin{array}{l}\text { Kemampuan karyawan hotel dalam menjelaskan produk } \\
\text { hotel }\end{array}$ \\
\hline & & $\begin{array}{l}\text { Kemampuan karyawan hotel da la m menjawab pertanyaan } \\
\text { tamu }\end{array}$ \\
\hline & & $\begin{array}{l}\text { Adanya respon yang baik terhadap keinginan konsumen } \\
\text { berkaitan dengan produk kamar yang ditawarkan }\end{array}$ \\
\hline & & Hotel menyediakan kebutuhan sesuai keinginan tamu \\
\hline & $\begin{array}{l}\text { Relasi Publik } \\
\text { (Public Relation) }\end{array}$ & $\begin{array}{l}\text { Hubungan pemasar dengan konsumen dapat mempengaruhi } \\
\text { keputusan membeliproduk hotel }\end{array}$ \\
\hline \multirow{4}{*}{$\begin{array}{l}\text { Harga } \\
\text { (Price) } \\
\mathrm{X} 2\end{array}$} & Tingkat Harga & Adanya harga pada setiap produk dan fasilita s hotel \\
\hline & StrukturDiskon & Adanya potongan harga yang menarik \\
\hline & $\begin{array}{l}\text { Tingkat Diskriminasi } \\
\text { Harga }\end{array}$ & Harga yang diberikan sesuai untuk diberikan kepada tamu \\
\hline & Syarat Pembayaran & Kemudahan dalam melakukan pembayaran \\
\hline \multirow{6}{*}{$\begin{array}{l}\text { Keputusan Pembelian } \\
(\mathrm{Y})\end{array}$} & Pengenalan Kebutuhan & $\begin{array}{l}\text { Hotel memberikan produk dan fasilitas sesuai dengan } \\
\text { kebutuhantamu }\end{array}$ \\
\hline & \multirow{4}{*}{ Pencarian Informasi } & Hotelmengetahuifaktor-faktor kebutuhan tamu \\
\hline & & Mencari informasi sendiri tentang hotel \\
\hline & & Mencari informasi dari sumber promosi \\
\hline & & Mencari informasi dari review tamu yang sudah menginap \\
\hline & Evaluasi Alternatif & Membandingkan hotel ini dengan hotel lainnya \\
\hline
\end{tabular}




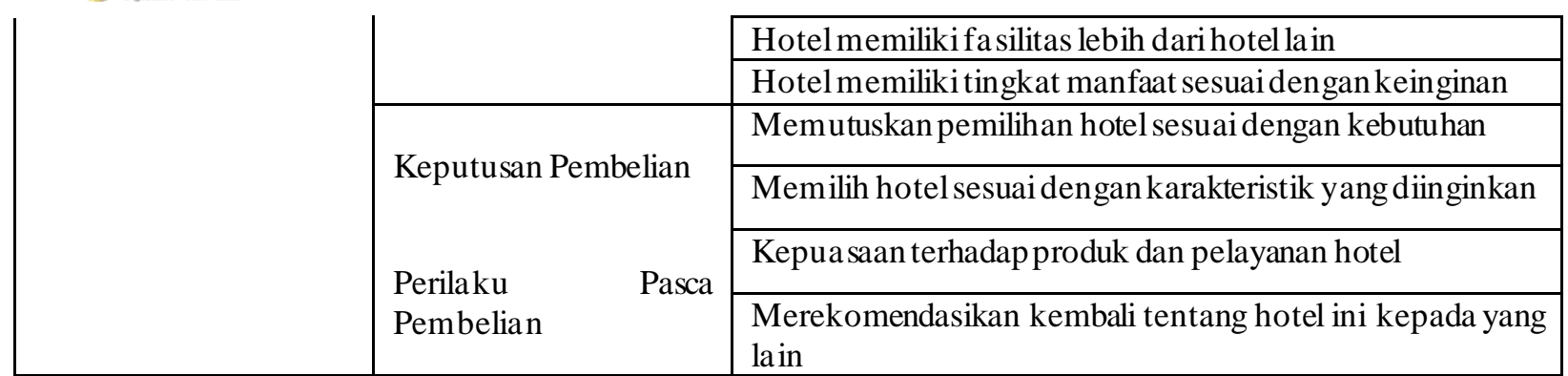

Sumber : Data Olahan Peneliti, 2019

\section{Pengujian validitas}

Data adalah hal yang sangat penting pada suatu penelitian, karena data adalah gambaran mengenai variabel yang diteliti dan fungsinya sebagai pembentukan hipotesis. Kualitas dari hasill penelitian ditentukan dari benar atau tidaknya data. Benar atau tidaknya data tergantung dari baik atau tidaknya item pengumpulan data. Valid dan reliable ialah syarat penting untuk instrument yang baik.

Dalam penelitian ini, yang akan diuji adalah validitas dari variabel promosi dan harga sebagai item variabel $\mathrm{X}_{1}$ dan $\mathrm{X}_{2}$ serta proses keputusan pembelian sebagai variabel $\mathrm{Y}$. Rumus yang digunakan untuk uji validitas menggunakan nilai korelasi skor total yang memakai teknik Korelasi Product Moment.

Dengan mencari nilai validitas dari semua item, kita akan mengkorelasikan skor item tersebut dengan total item-item dari variabel tersebut. Item-item tersebut jika korelasinya sama atau diatas 0,3 maka item tersebut dinyatakan valid, tetapi apabila nilai korelasinya dibawah 0,3 maka item tersebut dinyatakan tidak valid.

Tabel 3. Hasil Uji Validitas Promosi, Harga dan Keputusan Pembelian

No

ITEM $\mathbf{r}_{\text {hitung }}$

0.715

0.925

0.925

0.490

0.771

0.625

0.771

$\mathbf{r}_{\text {kritis }}$

VALIDITAS

$\mathbf{r}_{\text {hitung }}>\mathbf{r}_{\text {kritis }}$

\section{Promosi}

5

X1.5

X1.6

$\mathrm{X} 1.7$

0.3

Valid

0.3

Valid

6

7

0.3

Valid

Valid

Valid

Valid

0.3

Valid 


$\begin{array}{lllll}8 & \text { X1.8 } & 0.771 & 0.3 & \text { Valid } \\ 9 & \text { X1.9 } & 0.864 & 0.3 & \text { Valid } \\ 10 & \text { X1.10 } & 0.864 & 0.3 & \text { Valid } \\ 11 & \text { X1.11 } & 0.797 & 0.3 & \text { Valid } \\ 12 & \text { X1.12 } & 0.550 & 0.3 & \text { Valid } \\ 13 & \text { X1.13 } & 0.864 & 0.3 & \text { Valid }\end{array}$

\section{Harga}

$\begin{array}{lllll}1 & \text { X2.1 } & 0.807 & 0.3 & \text { Valid } \\ 2 & \text { X2.2 } & 0.913 & 0.3 & \text { Valid } \\ 3 & \text { X2.3 } & 0.913 & 0.3 & \text { Valid } \\ 4 & \text { X2.4 } & 0.621 & 0.3 & \text { Valid }\end{array}$

\section{Keputusan Pembelian}

$\begin{array}{lcccc}1 & \text { Y1 } & 0.906 & 0.3 & \text { Valid } \\ 2 & \text { Y.2 } & 0.507 & 0.3 & \text { Valid } \\ 3 & \text { Y.3 } & 0.792 & 0.3 & \text { Valid } \\ 4 & \text { Y.4 } & 0.641 & 0.3 & \text { Valid } \\ 5 & \text { Y.5 } & 0.685 & 0.3 & \text { Valid } \\ 6 & \text { Y.6 } & 0.685 & 0.3 & \text { Valid } \\ 7 & \text { Y.7 } & 0.890 & 0.3 & \text { Valid } \\ & & & & \text { Valid }\end{array}$




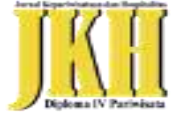

9

Y.9

10

Y.10

Y.11

12

Y.12

0.902

0.797

0.528

0.890

Sumber : Hasil penelitian, 2019

\section{Pengujian Reliabilitas}

Pengujian reliabilitas menerangkan bahwa suatu instrumen cukup untuk dapat digunakan sebagai alat kumpul data. Hasil penelitian dinyatakan reliabel apabila terdapat kesamaan data dalam kurun waktu yang berbeda. Instrumen yang reliabel berarti instrumen yang bila digunakan beberapa kali untuk mengukur objek yang sama, akan menghasilkan data yang sama (Sugiyono, 2013:348).

Apabila suatu instrumen dapat dipercaya, maka data yang dihasilkan oleh instrument tersebut dapat dipercaya juga. Pengujian reliabilitas untuk kuesioner penelitian dilakukan dengan menggunakan rumus Alfa Cronbach. Rumus Alfa Cronbach digunakan untuk mencari reliabilitas instrument yang skornya bukan 1 dan 0 , misalnya kuesioner atau angket, atau juga soal bentuk uraian.

Keputusan uji reliabilitas ditentukan dengan ketentuan sebagai berikut:

1. Jika koefisien internal seluruh item $r$ hitung $\geq r_{\text {tabel }}$ dengan tingkat signifikasi 0,05 (5\%), maka item pertanyaan dikatakan reliabel.

2. Jika koefisien internal seluruh item $r_{\text {hitung }}<r_{\text {tabel }}$ dengan tingkat signifikasi 0,05 (5\%), maka item pertanyaan dikatakan tidak reliabel.

3. Instrumen yang reliable adalah instrumen dengan nilai reliabilitas cronbach alpha diatas 0,6 .

Berdasarkan hasil perhitungan peneliti dengan menggunakan IBM SPSS 25 maka diperoleh hasil sebagai berikut :

Tabel 4. Hasil Uji Reliabilitas Promosi, Harga dan Keputusan Pembelian

$\begin{array}{lllll}\text { No } & \text { Item } & \mathbf{r}_{\text {hitung }} & \mathbf{r}_{\text {kritis }} & \text { Reliable } \\ & & & & \mathbf{r}_{\text {hitung }}>\mathbf{r}_{\text {kritis }}\end{array}$

\section{PROMOSI}

$\begin{array}{lllll}1 & \text { X1.1 } & 0.715 & 0.6 & \text { Reliable } \\ 2 & \text { X1.2 } & 0.925 & 0.6 & \text { Reliable } \\ 3 & \text { X1.3 } & 0.925 & 0.6 & \text { Reliable } \\ 4 & \text { X1.4 } & 0.490 & 0.6 & \text { Reliable }\end{array}$




$\begin{array}{lllll}5 & \text { X1.5 } & 0.771 & 0.6 & \text { Reliable } \\ 6 & \text { X1.6 } & 0.625 & 0.6 & \text { Reliable } \\ 7 & \text { X1.7 } & 0.771 & 0.6 & \text { Reliable } \\ 8 & \text { X1.8 } & 0.771 & 0.6 & \text { Reliable } \\ 9 & \text { X1.9 } & 0.864 & 0.6 & \text { Reliable } \\ 10 & \text { X1.10 } & 0.864 & 0.6 & \text { Reliable } \\ 11 & \text { X1.11 } & 0.797 & 0.6 & \text { Reliable } \\ 12 & \text { X1.12 } & 0.550 & 0.6 & \text { Reliable } \\ 13 & \text { X1.13 } & 0.864 & 0.6 & \text { Reliable }\end{array}$

\section{HARGA}

$\begin{array}{lllll}1 & \text { X2.1 } & 0.807 & 0.6 & \text { Reliable } \\ 2 & \text { X2.2 } & 0.913 & 0.6 & \text { Reliable } \\ 3 & \text { X2.3 } & 0.913 & 0.6 & \text { Reliable } \\ 4 & \text { X2.4 } & 0.621 & 0.6 & \text { Reliable }\end{array}$

\section{KEPUTUSAN PEMBELIAN}

$\begin{array}{lcccc}1 & \text { Y1 } & 0.906 & 0.6 & \text { Reliable } \\ 2 & \text { Y2 } & 0.507 & 0.6 & \text { Reliable } \\ 3 & \text { Y3 } & 0.792 & 0.6 & \text { Reliable } \\ 4 & \text { Y4 } & 0.641 & 0.6 & \text { Reliable } \\ & & & & \\ 5 & \text { Y5 } & 0.685 & 0.6 & \text { Reliable }\end{array}$




$\begin{array}{lcccc}6 & \text { Y6 } & 0.685 & 0.6 & \text { Reliable } \\ 7 & \text { Y7 } & 0.890 & 0.6 & \text { Reliable } \\ 8 & \text { Y8 } & 0.890 & 0.6 & \text { Reliable } \\ 9 & \text { Y9 } & 0.797 & 0.6 & \text { Reliable } \\ 10 & \text { Y10 } & 0.528 & 0.6 & \text { Reliable } \\ 11 & \text { Y11 } & 0.890 & 0.6 & \text { Reliable } \\ 12 & \text { Y12 } & 0.902 & 0.6 & \text { Reliable }\end{array}$

Sumber : Hasil penelitian, 2019

\section{Analisis Data}

\section{Analisis Data Deskriptif}

Berdasarkan pendapat dari Sugiyono (2013:29), “analisis ini berfungsi untuk menggambarkan objek penelitian lewat data sampling apa adanya tanpa membuat kesimpulan secara umum. Selain itu juga, teknik ini mencari tahu seberapa kuat hubungan antara variabel satu dengan yg lainnyalewat analisis korelasi dan membandingkan average data sample tanpa signifikasinya diuji.

\section{Analisis Data Verifikatif}

Analisis verifikatif bertujuan untuk menguji hipotesis dengan menggunakan uji statistik. Melalui metode verifikatif, maka hubungan antar variabel dari masalah yang sedang diselidiki di dalam hipotesis dapat diuji secara matematis, atau dengan kata lain, penelitian tersebut dapat diuji kebenaran hipotesisnya. Sebagai langkah untuk verifikasi hasil penelitian digunakan path analysis. Jalur yang digunakan untuk menentukan besarnya variabel independen $\left(X_{1}\right.$ dan $\left.X_{2}\right)$ dimana promosi sebagai $X_{1}$ dan harga sebagai $\mathrm{X}_{2}$ terhadap Keputusan Pembelian sebagai $\mathrm{Y}$ baik secara langsung maupun tidak langsung, dengan pengujian hipotesis dilakukan dengan struktur berikut:

\section{Gambar 1. Struktur Hubungan Kausal X dan Y}

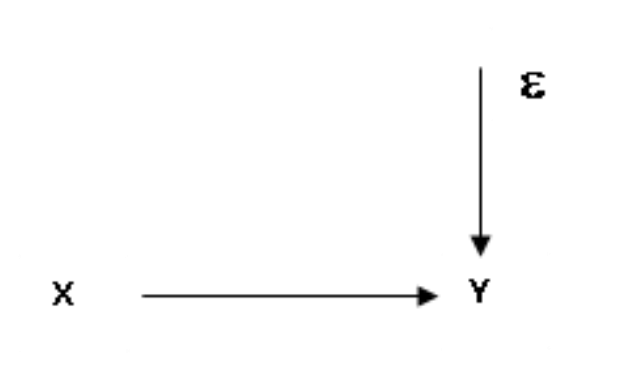

Keterangan:

$$
\mathrm{X}=\text { Promosi dan Harga }
$$


$\mathrm{Y}=$ Keputusan Pembelian

$\varepsilon=$ Variabel lain

Struktur Hubungan antara X dan Y diuji melalui analisis jalur dengan hipotesis yang berbunyi terdapat pengaruh yang signifikan antara promosi, harga terhadap keputusan pembelian. Selanjutnya struktur hubungan diatas diterjemahkan kedalam hipotesis yang menyatakan pengaruh variabel bebas yang dominan terhadap variabel terikat sesuai model berikut:

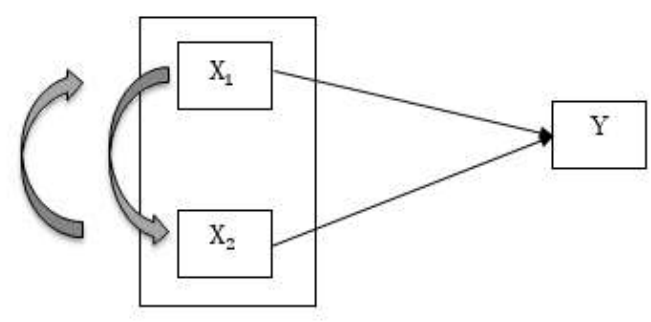

Gambar 2. Model Analisis Jalur

Keterangan :

$$
\begin{aligned}
& \mathrm{X}_{1}=\text { Promosi } \\
& \mathrm{X}_{2}=\text { Harga } \\
& \mathrm{Y}=\text { Proses keputusan Pembelian }
\end{aligned}
$$

Setelah dihitung besaran nilai korelasinya, dilanjutkan identifikasi pengaruh secara langsung dan tidak langsung dari setiap variabelnya. Selanjutnya, menghitung pengaruh $\mathrm{X}_{1}$ kepada $\mathrm{Y}$ dan $\mathrm{X}_{2}$ kepada Y menggunakan persamaan:

a. Pengaruh $\mathrm{X}_{1}$ terhadap $\mathrm{Y}$

Pengaruh tidak langsung melalui $\left(\mathrm{X}_{2}\right)=\left(\mathrm{R} \mathrm{X}_{1} \mathrm{X}_{2}\right)\left(\mathrm{PL} \mathrm{X}_{1}\right)\left(\mathrm{PL} \mathrm{X}_{2}\right)$

Pengaruh total $\mathrm{X}_{1}$ terhadap $\mathrm{Y}=$

b. Pengaruh $\mathrm{X}_{2}$ terhadap $\mathrm{Y}$

Pengaruh tidak langsung melalui $\left(\mathrm{X}_{1}\right)=\left(\mathrm{R} \mathrm{X}_{1} \mathrm{X}_{2}\right)(\mathrm{PL} \mathrm{X})_{1}\left(\mathrm{PL} \mathrm{X}_{2}\right)$

Pengaruh total $\mathrm{X}_{2}$ terhadap $\mathrm{Y}=$

Keterangan :

$\mathrm{R}$ = Nilai Korelasi

PL = Nilai Pengaruh Langsung

\section{Hipotesis Penelitian}

Peneliti memberikan jawaban sementara berdasarkan teori yang sesuai dan belum dibuat berdasarkan pada data empiris. Oleh sebab itu, diperlukan adanya pembuktian mengenai kebenaran dari hipotesis yang dibuktikan melalui data yang terkumpul. Adapun hipotesis yang diajukan yaitu secara simultan dan parsial.

Hipotesis secara simultan

Jika $\mathrm{F}_{\text {hitung }}>\mathrm{F}_{\text {tabel, }}$ maka $\mathrm{H}_{0}$ ditolak dan $\mathrm{H}_{\mathrm{a}}$ diterima.

$\mathrm{H}_{0}: \mathrm{P}_{\mathrm{yx}}=0$ Tidak terdapat pengaruh yang signifikan antara promosi dan harga terhadap keputusan pembelian tamu di hotel berbintang 3 (tiga) Kota Palembang.

$\mathrm{H}_{\mathrm{a}}: \mathrm{P}_{\mathrm{yx}} \neq 0$ Terdapat pengaruh yang signifikan antara promosi dan harga terhadap proses keputusan pembelian tamu di hotel berbintang 3 (tiga) Kota Palembang. 
Hipotesis secara parsial

Jika $t_{\text {hitung }}>\mathrm{t}_{\text {tabel}}$, dengan nilai signifikansi $<0,05$ maka $\mathrm{H}_{0}$ ditolak dan $\mathrm{H}_{1}$ diterima.

$\mathbf{H}_{\mathbf{0}, \mathbf{1}}: \mathbf{b}_{\mathbf{1}}=\mathbf{0}$ Tidak terdapat pengaruh yang signifikan antara promosi terhadap keputusan pembelian tamu di hotel berbintang 3 (tiga) Kota Palembang.

$\mathbf{H}_{\mathbf{a}, \mathbf{1}}: \mathbf{b}_{\mathbf{1}} \neq \mathbf{0}$ Terdapat pengaruh yang signifikan antara promosi terhadap keputusan pembelian tamu di hotel berbintang 3 (tiga) Kota Palembang.

$\mathbf{H}_{\mathbf{0}, \mathbf{2}}: \mathbf{b}_{\mathbf{1}}=\mathbf{0}$ Tidak terdapat pengaruh yang signifikan antara harga terhadap keputusan pembelian tamu di hotel berbintang 3 (tiga) Kota Palembang.

$\mathbf{H}_{\mathbf{a}, 2}: \mathbf{b}_{1} \neq \mathbf{0}$ Terdapat pengaruh yang signifikan antara harga terhadap keputusan pembelian tamu di hotel berbintang 3 (tiga) Kota Palembang.

\section{HASIL DAN PEMBAHASAN Profil Responden}

Peneliti telah mengumpulkan data dari 393 responden yaitu tamu yang menginap di beberapa lokus hotel yaitu Santika Radial, Batiqa Hotel Palembang, dan Hotel Swarna Dwipa Palembang selama periode bulan Agustus 2018 - November 2018.

Gambar 3 menunjukkan bahwa jumlah responden yang datang ke hotel berbintang tiga yaitu Hotel Santika Radial, Batiqa Hotel Palembang, dan Hotel Swarna Dwipa Palembang didominasi dengan usia 31- 45 tahun merupakan jumlah yang paling banyak dengan jumlah 180 responden. Selanjutnya disusul dengan 136 responden berusia 26 - 30 tahun dengan 46 responden berusia 21 - 25 tahun kemudian 18 responden dengan usia $<20$ tahun dan yang paling sedikit 13 responden dengan usia $>45$ tahun.

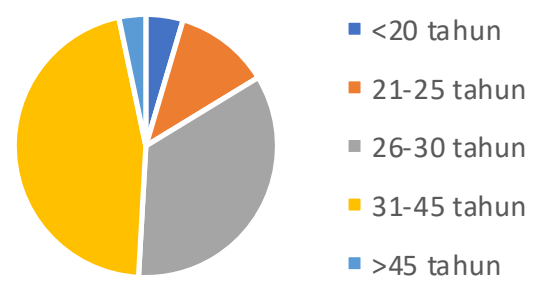

Gambar 3. Usia Responden

Sumber : Hasil penelitian, 2019

Gambar 4. Pendapatan Responden

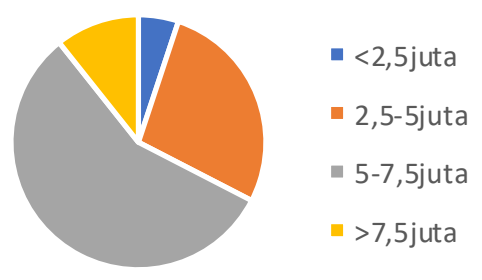

Sumber : Hasil penelitian, 2019

Berdasarkan gambar 4, jumlah responden yang datang ke hotel berbintang tiga yaitu Hotel Santika Radial, Batiqa Hotel Palembang, dan Hotel Swarna Dwipa Palembang memiliki pendapatan antara 5 7,5 juta merupakan jumlah yang paling banyak dengan 223 responden. Selanjutnya disusul dengan 108 responden yang memiliki pendapatan antara 2,5 - 5 juta kemudian 42 responden dengan pendapatan $>$ 7,5 juta dan yang paling sedikit 20 responden dengan pendapatan $<2,5$ juta. 
Gambar 5. Gender Responden

Sumber : Hasil penelitian, 2019

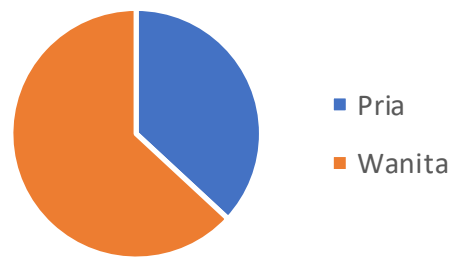

Gambar 5 mengindikasikan jumlah responden didominasi dengan jenis kelamin wanita yang memiliki jumlah lebih banyak dengan 248 responden disbanding dengan kelamin pria sebanyak 145 responden. Gambar 6 menunjukan jumlah responden dengan pekerjaan sebagai pegawai swasta sebanyak 210 responden merupakan jumlah yang tertinggi, selanjutnya disusul 123 responden dengan pekerjaan sebagai pegawai negeri, 28 responden dengan pekerjaan sebagai wiraswasta, 17 responden dengan pekerjaan sebagai mahasiswa dan sisanya yang bekerja dengan profesi lainnya sebanyak 15 responden.

Gambar 6. Profesi Responden

Sumber : Hasil penelitian, 2019

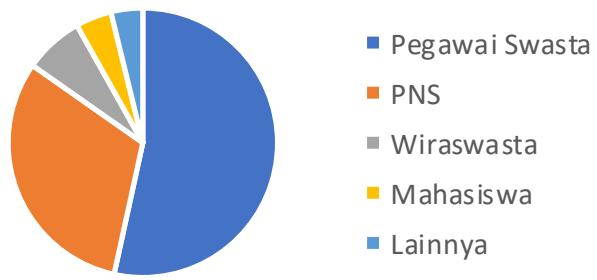

Gambar 7. Asal Daerah Responden

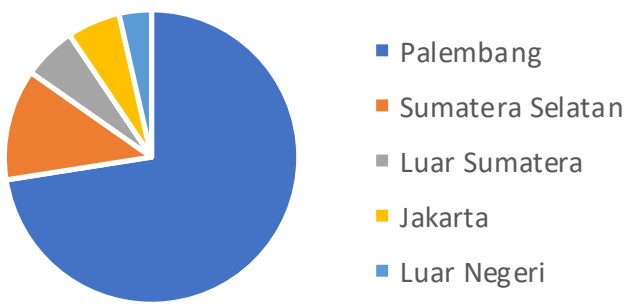

Sumber : Hasil penelitian, 2019

Berdasarkan gambar 7, jumlah responden yang berasal dari kota Palembang merupakan yang paling dominan sebanyak 285 responden, selanjutnya disusul dengan responden yang berasal dari Provinsi Sumatera Selatan sebanyak 48 responden, responden yang datang dari Jakarta 23 responden kemudian responden berasal dari luar Sumatera sebanyak 23 responden dan 14 responden yang berasal dari luar negeri. 


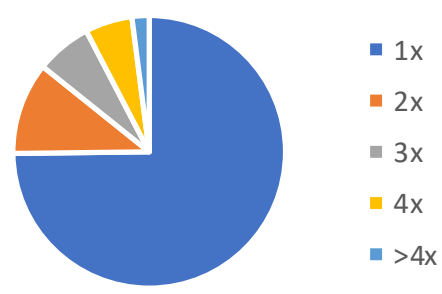

Gambar 8. Jumlah Kunjungan Responden

Sumber: Hasil penelitian, 2019

Berdasarkan gambar 8 dapat dilihat bahwa responden melakukan kunjungan pertama kali ke hotel ditempat mereka menginap sekarang dimana jumlah yang paling banyak dengan 294 responden. Selanjutnya disusul dengan responden yang berkunjung kedua kalinya yaitu 43 responden, 26 responden yang berkunjung untuk ketiga, responden yang berkunjung empat kali. 22 responden dan lebih dari empat kali serta yang paling sedikit sebanyak 8 responden.

Gambar 9 menunjukkan responden yang pernah datang ke hotel bintang tiga mendapatkan informasi paling banyak adalah melalui sales tim yaitu 188 responden, selanjutnya disusul dengan responden yang mendapatkan informasi melalui media sosial berjumlah 7 responden, yang mendapatkan informasi dari sumber lainnya berjumlah 33 responden, yang mendapatkan informasi dari media cetak berjumlah 43 responden dan yang paling sedikit adalah responden yang mendapatkan informasi dari media elektronik yaitu berjumlah 7 responden.

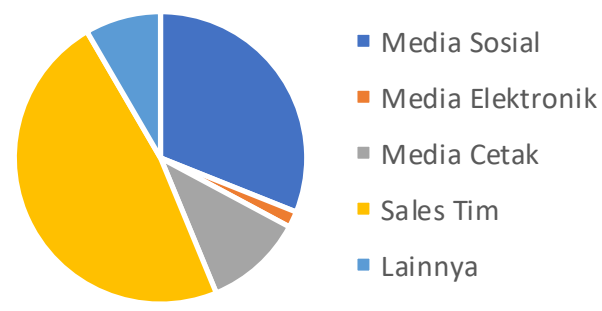

Gambar 9. Sumber Informasi Responden

Sumber : Hasil penelitian, 2019

\section{Deskripsi Tanggapan Responden}

Dari 13 pernyataan, hasil rata-rata terbanyak jawaban para responden adalah pernyataan setuju yaitu sebanyak 11 pernyataan. Secara rata-rata, dari 393 responden yang diteliti mempunyai tanggapan 3.67 yang dalam kategori setuju. Berdasarkan dari garis kontinum skala 1 hingga 5, posisi rata-rata terdapat pada 3,67. Nilai tersebut terletak pada posisi tinggi. Hal tersebut dapat disimpulkan responden memberikan tanggapan Setuju kepada variabel promosi di Hotel Bintang 3 di Palembang.

Tabel 7. Tanggapan Responden terhadap Variabel $\mathrm{X}_{1}$

\begin{tabular}{|l|l|l|l|l|l|l|l|}
\hline \multirow{2}{*}{ Kuesioner } & \multicolumn{5}{|l|}{ Jawaban Responden } & \multirow{2}{*}{ Jlh. } & \multirow{2}{*}{ Rerata } \\
\cline { 2 - 7 } & STS & TS & CS & S & SS & & \\
\hline X1.1 & 0 & 56 & 210 & 1056 & 155 & 1477 & 3.76 \\
\hline X1.2 & 0 & 0 & 873 & 252 & 195 & 1320 & 3.36 \\
\hline
\end{tabular}




\begin{tabular}{|l|l|l|l|l|l|l|l|}
\hline X1.3 & 0 & 0 & 993 & 108 & 175 & 1276 & 3.25 \\
\hline X1.4 & 0 & 24 & 177 & 1180 & 135 & 1516 & 3.86 \\
\hline X1.5 & 32 & 502 & 96 & 188 & 155 & 973 & 2.48 \\
\hline X1.6 & 0 & 24 & 741 & 348 & 235 & 1348 & 3.43 \\
\hline X1.7 & 0 & 0 & 192 & 1176 & 175 & 1543 & 3.93 \\
\hline X1.8 & 0 & 0 & 24 & 1400 & 175 & 1599 & 4.07 \\
\hline X1.9 & 0 & 24 & 48 & 1224 & 295 & 1591 & 4.05 \\
\hline X1.10 & 4 & 8 & 48 & 1272 & 255 & 1587 & 4.04 \\
\hline X1.11 & 4 & 16 & 777 & 348 & 175 & 1320 & 3.36 \\
\hline X1.12 & 4 & 16 & 156 & 856 & 575 & 1607 & 4.09 \\
\hline X1.13 & 0 & 32 & 132 & 1064 & 335 & 1563 & 3.98 \\
\hline Rerata Total : & \multicolumn{7}{|l|}{} \\
\hline
\end{tabular}

Sumber : Hasil penelitian, 2019

Tabel 8. Tanggapan Responden pada Variabel $\mathrm{X}_{2}$

\begin{tabular}{|c|c|c|c|c|c|c|c|}
\hline \multirow{2}{*}{ Kuesioner } & \multicolumn{5}{|c|}{ Jawaban Responden } & \multirow{2}{*}{ Jlh. } & \multirow[t]{2}{*}{ Rerata } \\
\hline & STS & $\mathbf{T S}$ & $\mathrm{CS}$ & $\mathbf{S}$ & $\overline{S S}$ & & \\
\hline $\mathrm{X} 2.1$ & 0 & 56 & 210 & 1056 & 155 & 1477 & 3.76 \\
\hline $\mathrm{X} 2.2$ & 0 & 0 & 873 & 252 & 195 & 1320 & 3.36 \\
\hline $\mathrm{X} 2.3$ & 0 & 0 & 993 & 108 & 175 & 1276 & 3.25 \\
\hline $\mathrm{X} 2.4$ & 0 & 24 & 177 & 1180 & 135 & 1516 & 3.86 \\
\hline \multicolumn{7}{|c|}{ Rerata Total : } & 3.55 \\
\hline
\end{tabular}

Sumber: Hasil penelitian, 2019

Dari 4 pernyataan, jawaban responden terdapat 2 pernyataan yang setuju dan 2 pernyataan cukup setuju. Secara rata-rata, dari 393 responden yang diteliti mempunyai tanggapan sebesar 3.55 atau setuju. Jika dilihat berdasarkan garis kontinum skala 1 hingga 5, posisi poin 3,55 berada pada kategoti sedang. Hal ini menggambarkan bahwa faktor harga memiliki pengaruh terhadap keputusan pembelian, tetapi kekuatan sedang. Hal ini kemungkinan dibutuhkan dukungan dari faktor lain untuk menjadikan pengaruhnya kuat atau juga dibutuhkan perantara faktor lain yang mendukung agar menjadi lebih kuat dalam mempengaruhi keputusan pembelian.

Tabel 9. Tanggapan Responden pada Variabel Y

\begin{tabular}{|c|c|c|c|c|c|c|c|}
\hline \multirow{2}{*}{ Kuesioner } & \multicolumn{5}{|c|}{ Jawaban Responden } & \multirow{2}{*}{ Jlh } & \multirow{2}{*}{ Rerata } \\
\hline & STS & TS & CS & $\mathbf{S}$ & SS & & \\
\hline $\mathrm{Y} 1$ & 0 & 0 & 993 & 108 & 175 & 1276 & 3.25 \\
\hline $\mathrm{Y} 2$ & 0 & 24 & 177 & 1180 & 135 & 1516 & 3.86 \\
\hline $\mathrm{Y3}$ & 32 & 502 & 96 & 188 & 155 & 973 & 2.48 \\
\hline $\mathrm{Y} 4$ & 0 & 24 & 741 & 348 & 235 & 1348 & 3.43 \\
\hline Y5 & 0 & 0 & 192 & 1176 & 175 & 1543 & 3.93 \\
\hline Y6 & 0 & 0 & 24 & 1400 & 175 & 1599 & 4.07 \\
\hline $\mathrm{Y7}$ & 0 & 24 & 48 & 1224 & 295 & 1591 & 4.05 \\
\hline Y8 & 4 & 8 & 48 & 1272 & 255 & 1587 & 4.04 \\
\hline Y9 & 4 & 16 & 777 & 348 & 175 & 1320 & 3.36 \\
\hline Y10 & 4 & 16 & 156 & 856 & 575 & 1607 & 4.09 \\
\hline Y11 & 0 & 32 & 132 & 1064 & 335 & 1563 & 3.98 \\
\hline Y12 & 0 & 0 & 753 & 268 & 375 & 1396 & 3.55 \\
\hline \multicolumn{7}{|l|}{ erata Total } & 3.67 \\
\hline
\end{tabular}

Sumber: Hasil penelitian, 2019 
Dari 12 pernyataan, jawaban responden secara rata-rata yang paling banyak adalah pernyataan setuju yaitu sebanyak 9. Secara rata-rata, dari 393 responden yang diteliti mepunyai tanggapan sebesar 3.69 atau setuju. Berdasarkan garis kontinum dengan menggunakan skala 1 hingga 5, dengan nilai 3,69 berada pada posisi tinggi. Hal ini menunjukan responden memberikan tanggapan setuju terhadap variabel Y.

\section{Analisis Path}

Analisis verifikatif dalam penelitian ini bertujuan untuk menguji hipotesis dari variabel promosi, harga dan keputusan pembelian di Hotel Bintang 3 Kota Palembang. Untuk menganalisis data verifikatif dalam penelitian ini digunakan analisis jalur (path analysis) terkait bagaimana variabel terikat $Y$ atau variabel endogen dipengaruhi oleh variabel bebas $\mathrm{X}$ yang disebut eksogen melalui model atau persamaan struktural. Hasil pengolahan data statistik berupa korelasi antar variabel pada tabel berikut:

Tabel 10. Matrik Korelasi antar Variabel Harga Dan Promosi Terhadap Keputusan Pembelian

\section{Correlations}

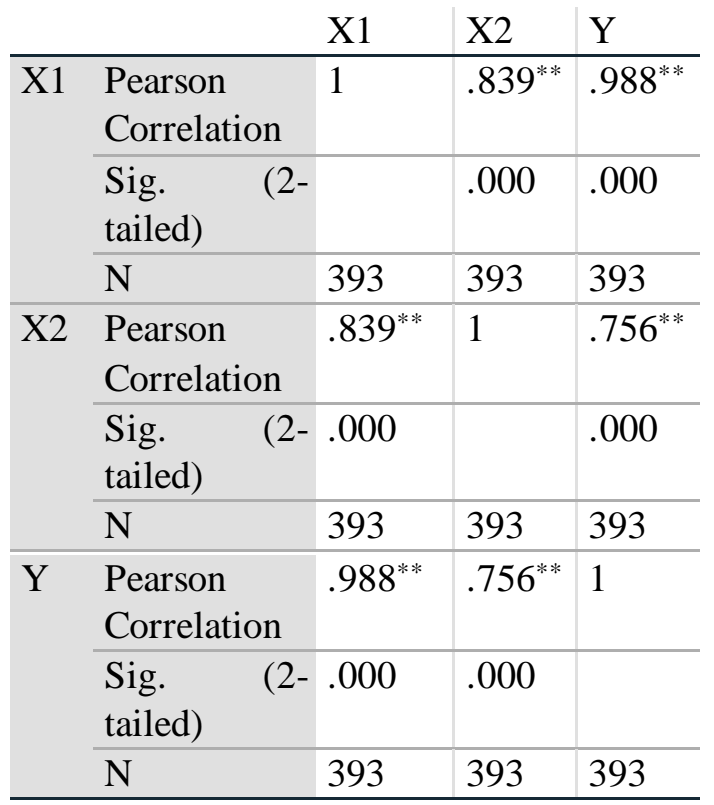

**. Correlation is significant at the 0.01 level (2-tailed).

Sumber: Hasil pengolahan data, SPSS 25

Berdasarkan hasil matriks korelasi pada tabel 10, dapat diketahui hubungan antara variabel promosi dan harga terhadap keputusan pembelian. Berdasarkan hasil uji korelasi antara variabel $X_{1}$ dan $X_{2}$ dengan variabel Y menegaskan bahwa hubungan antara variabel promosi terhadap proses keputusan pembelian merupakan hubungan antar variabel dengan nilai korelasi yaitu 0.988 , hubungan antara variabel harga terhadap proses keputusan pembelian merupakan hubungan antar variabel dengan nilai korelasi yaitu 0.756 , sedangkan hubungan antara variabel $\mathrm{X}_{1}$ dan $\mathrm{X}_{2}$ merupakan hubungan antar variabel dengan nilai korelasi yaitu adalah sebesar 0.839. Berdasarkan hasil tersebut, korelasi antara promosi terhadap keputusan pembelian dapat dikatakan sangat kuat dan korelasi antara harga dan keputusan pembelian dinyatakan kuat.

\section{Uji Simultan}

Untuk dapat mengetahui seberapa jauh pengaruh promosi dan harga terhadap proses keputusan pembelian secara simultan, dilakukan pengujian hipotesis, dengan hasil uji $\mathrm{F}$ berikut: 
Tabel 11.Pengujian Hipotesis Secara Simultan (Uji F)

\begin{tabular}{|c|c|c|c|c|c|}
\hline ANOVA $^{\mathbf{a}}$ & & & & & \\
\hline Model & $\begin{array}{l}\text { Sum } \\
\text { of } \\
\text { Squa } \\
\text { res }\end{array}$ & $\mathrm{df}$ & $\begin{array}{l}\text { Mea } \\
n \\
\text { Squa } \\
\text { re }\end{array}$ & $\mathrm{F}$ & Sig. \\
\hline $\begin{array}{l}1 \text { Regressi } \\
\text { on }\end{array}$ & $\begin{array}{l}1110 \\
4.57 \\
3\end{array}$ & 2 & $\begin{array}{l}5552 \\
.286\end{array}$ & $\begin{array}{l}3803 \\
7.075\end{array}$ & $\begin{array}{l}.000 \\
\mathrm{~b}\end{array}$ \\
\hline Residual & $\begin{array}{l}56.9 \\
28\end{array}$ & 390 & .146 & & \\
\hline Total & $\begin{array}{l}1116 \\
1.50 \\
1\end{array}$ & 392 & & & \\
\hline
\end{tabular}

Sumber: Hasil pengolahan data, SPSS 25

Rumusan hipotesis penelitian:

$$
\begin{aligned}
\mathrm{H}_{0}: \rho= & \text { artinya tidak terdapat pengaruh } \\
0 & \text { yang signifikan antara promosi } \\
& \text { dan harga terhadap keputusan } \\
& \text { pembelian di Hotel Bintang 3 } \\
& \text { Kota Palembang } \\
\mathrm{H}_{\mathrm{a}}: \rho_{\neq} 0 \quad & \text { artinya terdapat pengaruh yang } \\
& \text { signifikan antara promosi dan } \\
& \text { harga terhadap keputusan } \\
& \text { pembelian di Hotel Bintang 3 } \\
& \text { Kota Palembang }
\end{aligned}
$$

Dari tabel 11 dapat dilihat bahwa nilai $F_{\text {hitung }}$ sebesar 38037.075, sedangkan $F_{\text {tabel }}$ dengan derajat kebebasan pada tingkat 0,05 adalah sebesar 3.0188 (2;390). Karena nilai $F_{\text {hitung }} 38037.075$ lebih besar dari nilai $\mathrm{F}_{\text {tabel }} 3.0188$, maka $\mathrm{H}_{0}$ ditolak dan $\mathrm{H}_{\mathrm{a}}$ diterima, bermakna bahwa promosi dan harga secara simultan berpengaruh terhadap keputusan pembelian di Hotel Bintang 3 Kota Palembang.

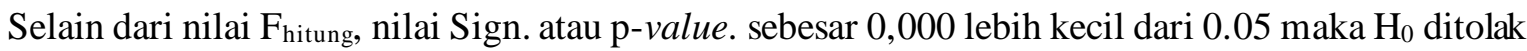
bermakna bahwa variabel promosi dan harga secara simultan berpengaruh terhadap variabel keputusan pembelian di Hotel Bintang 3 Kota Palembang. 


\section{Uji Parsial}

Pengujian selanjutnya setelah menunjukan hasil signifikan, maka dilakukan uji t. Menguji dengan partial ditujukan untuk mencari tahu besaran signifikansi dari setiap variabel yang diteliti.

Tabel 12. Output Jalur

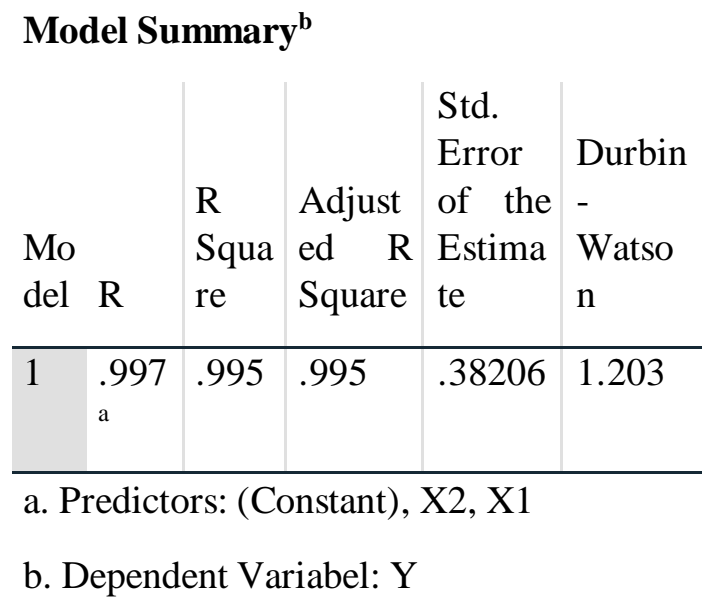

\section{Coefficients $^{\mathrm{a}}$}

\begin{tabular}{|c|c|c|c|c|c|c|c|}
\hline Model & \multicolumn{2}{|c|}{$\begin{array}{l}\text { Unstandar } \\
\text { dized } \\
\text { Coefficient } \\
\text { s }\end{array}$} & $\begin{array}{l}\text { Sta } \\
\text { nda } \\
\text { rdiz } \\
\text { ed } \\
\text { Co } \\
\text { effi } \\
\text { cie } \\
\text { nts } \\
\\
\text { Bet } \\
\text { a }\end{array}$ & $\mathrm{t}$ & $\begin{array}{l}\mathrm{Si} \\
\mathrm{g} .\end{array}$ & $\begin{array}{l}\text { Colli } \\
\text { ity } \\
\text { Statis } \\
\text { Tole } \\
\text { ranc } \\
\text { e }\end{array}$ & $\begin{array}{l}\text { hear } \\
\text { tics } \\
\text { VI } \\
\text { F }\end{array}$ \\
\hline $\begin{array}{l}1 \text { (Consta } \\
\mathrm{nt})\end{array}$ & $\begin{array}{l}- \\
.020\end{array}$ & .175 & & $\begin{array}{l}- \\
.1 \\
12\end{array}$ & $\begin{array}{l}.9 \\
11\end{array}$ & & \\
\hline $\mathrm{X} 1$ & $\begin{array}{l}1.04 \\
2\end{array}$ & .006 & $\begin{array}{l}1.1 \\
94\end{array}$ & $\begin{array}{l}17 \\
9 . \\
84 \\
2\end{array}$ & $\begin{array}{l}.0 \\
00\end{array}$ & .297 & $\begin{array}{l}3.3 \\
71\end{array}$ \\
\hline $\mathrm{X} 2$ & $\begin{array}{l}- \\
.660\end{array}$ & .018 & $\begin{array}{l}- \\
.24 \\
5\end{array}$ & $\begin{array}{l}- \\
36 \\
.9 \\
40\end{array}$ & $\begin{array}{l}.0 \\
00\end{array}$ & .297 & $\begin{array}{l}3.3 \\
71\end{array}$ \\
\hline
\end{tabular}




\section{a. Dependent Variabel: Y}

Sumber : Hasil pengolahan data, SPSS 25

Mengacu pada tabel 12, besarnya nilai $\mathrm{R}^{2}$ atau $\mathrm{R}$ Square yaitu sebesar 0,995 menunjukkan bahwa kontribusi pengaruh variabel $\mathrm{X}$ terhadap $\mathrm{Y}$ adalah sebesar $99,5 \%$. Sementara untuk mengetahui besarnya variabel lain yang mungkin mempengaruhi proses keputusan pembelian atau disebut dengan variabel epsilon yaitu sebesar 0,5 persen. Selanjutnya, dapat diketahui bahwa nilai signifikansi dari variabel $\mathrm{X}_{1}$ sebesar 0,000 dan $\mathrm{X}_{2}$ sebesar 0,000 adalah lebih kecil dari 0,05 memberikan kesimpulan bahwa variabel promosi dan variabel harga juga berpengaruh signifikan terhadap proses keputusan pembelian secara parsial.

Tabel 13. Pengujian Hipotesis Secara Parsial (Uji t)

\begin{tabular}{|lllllll|}
\hline $\begin{array}{l}\text { N Koefisien } \\
\text { O Regresi }\end{array}$ & Thitung & $\begin{array}{l}\text { Ttab } \\
\text { el }\end{array}$ & Sig & $\begin{array}{l}\text { Kepu } \\
\text { tusan }\end{array}$ & Ket. \\
\hline $\begin{array}{l}\text { 1 Promo } \\
\text { si }\end{array}$ & $\begin{array}{l}1.1949 \\
2\end{array}$ & $\begin{array}{l}1,9 \\
6\end{array}$ & $\begin{array}{l}0,00 \\
0\end{array}$ & $\begin{array}{l}\text { Ho } \\
\text { ditol } \\
\text { ak }\end{array}$ & $\begin{array}{l}\text { Signi } \\
\text { fi kan }\end{array}$ \\
\hline 2 Harga & - & -36.940 & $\begin{array}{l}1,9 \\
6\end{array}$ & $\begin{array}{l}0,00 \\
0\end{array}$ & $\begin{array}{l}\text { Ho } \\
\text { ditol } \\
\text { ak }\end{array}$ & $\begin{array}{l}\text { Signi } \\
\text { fi kan }\end{array}$ \\
\hline
\end{tabular}

Sumber: Hasil pengolahan data, SPSS 25

Berdasarkan tabel 13, hasil pengujian signifikansi dengan menggunakan uji t dilakukan dengan membandingkan $t_{\text {hitung }}$ dengan $t_{t a b e l}$. Pengaruh suatu variabel $X$ terhadap variabel $Y$ dinyatakan signifikan apabila $\left|t_{\text {hitung }}\right|>t_{\text {tabel }}$ dengan nilai signifikansi $<$ dari 0,05 sehingga menunjukkan terdapat variabel $\mathrm{X}_{1}$ dan $\mathrm{X}_{2}$ yang dinyatakan memiliki pengaruh signifikan dalam mempengaruhi variabel $\mathrm{Y}$, bermakna bahwa kedua variabel independen tersebut berpengaruh secara signifikan terhadap proses keputusan pembelian di Hotel Bintang 3 di Kota Palembang.

Diagram jalur antara promosi dan harga terhadap proses keputusan pembelian dapat dilihat pada gambar berikut:

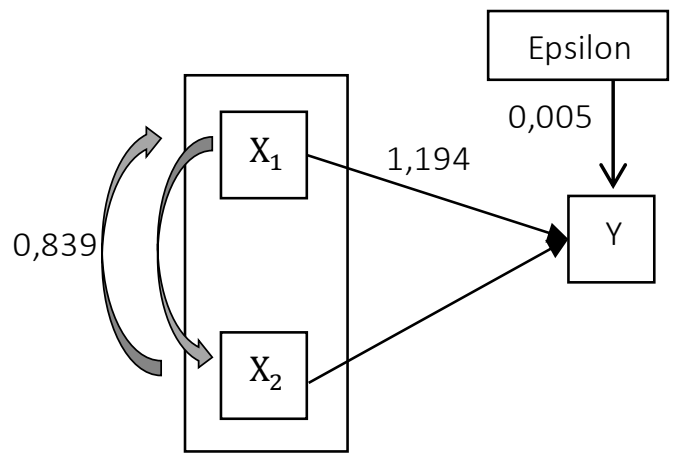

Gambar 10. Diagram Jalur

Sumber: Hasil penelitian, 2019.

Berdasarkan gambar 10, dapat dilihat hubungan antar variabel $\mathrm{X}$ beserta dengan nilai pengaruh masing-masing variabel $\mathrm{X}$ terhadap variabel $\mathrm{Y}$. Hubungan korelasi antara variabel promosi dan harga yaitu sebesar 0,839, maka dengan demikian hubungan korelasi antara promosi dan harga dinyatakan kuat. Sedangkan untuk pengaruh masing-masing variabel $\mathrm{X}$ terhadap variabel $\mathrm{Y}$ dapat dijelaskan bahwa pengaruh promosi terhadap proses keputusan pembelian sebesar 0,988 atau 98,8 persen sedangkan harga terhadap proses keputusan pembelian sebesar 0,756 atau 75,6 persen. 
Pengaruh tidak langsung $\mathrm{X}_{1}$ terhadap $\mathrm{Y}$ melalui $\mathrm{X}_{2}$ senilai $\left(\mathrm{R}_{1} \mathrm{X}_{2}\right)\left(\mathrm{P}_{\mathrm{L}} \mathrm{X}_{1}\right)\left(\mathrm{P}_{\mathrm{L}} \mathrm{X}_{2}\right)$ sebesar -0.2454 dan pengaruh tidak langsung $\mathrm{X}_{2}$ terhadap $\mathrm{Y}$ melalui $\mathrm{X}_{1}$ senilai $\left(\mathrm{R}_{1} \mathrm{X}_{2}\right)\left(\mathrm{PLX}_{1}\right)\left(\mathrm{PLX}_{2}\right)$ sebesar -0.2454. Nilai perhitungan koefisien jalur pengaruh langsung dan tidak langsung antara variabel $X$ dan variabel Y tertera pada tabel 14.

Tabel 14. Pengujian Koefisien Jalur

Pengaruh Langsung Dan Tidak Langsung

Sumber: Hasil penelitian, 2019

\begin{tabular}{|l|l|l|l|l|}
\hline \multirow{2}{*}{ Variabel } & \multirow{2}{*}{$\begin{array}{l}\text { Pengaruh } \\
\text { Langsung }\end{array}$} & \multicolumn{2}{l|}{$\begin{array}{l}\text { Pengaruh } \\
\text { Tidak }\end{array}$} & $\begin{array}{l}\text { Total } \\
\text { Lengsung } \\
\text { Tidak } \\
\text { Langsung }\end{array}$ \\
\cline { 3 - 5 } & $\mathrm{X}_{1}$ & $\mathrm{X}_{2}$ & Lang \\
\hline $\begin{array}{l}\text { Promosi } \\
\left(\mathrm{X}_{1}\right)\end{array}$ & 1,194 & & - & -0.2454 \\
\hline $\begin{array}{l}\text { Harga } \\
\left(\mathrm{X}_{2}\right)\end{array}$ & $-0,245$ & - & & -0.2454 \\
\hline
\end{tabular}

Analisis pengaruh $\mathrm{X}_{1}$ terhadap Y, nilai pengaruh langsung sebesar 1,194 lebih besar dibandingkan nilai pengaruh tidak langsung sebesar -0.2454 , yang artinya hasil ini menunjukkan bahwa secara langsung $\mathrm{X}_{1}$ berpengaruh terhadap $\mathrm{Y}$ melalui $\mathrm{X}_{2}$. Sedangkan pada analisis pengaruh $\mathrm{X}_{2}$ terhadap $\mathrm{Y}$, nilai pengaruh langsung sebesar -0,245 lebih kecil dibandingkan nilai pengaruh tidak langsung sebesar -0.2454 , yang artinya hasil ini menunjukkan bahwa secara tidak langsung $\mathrm{X}_{2}$ berpengaruh terhadap $\mathrm{Y}$ melalui $\mathrm{X}_{1}$.

Berdasarkan hasil pengujian hipotesis yang dilakukan secara simultan dan parsial dinyatakan bahwa seluruh variabel independen dinyatakan memiliki pengaruh yang signifikan. Oleh karena itu, maka hasil penelitian dapat sepenuhnya dijadikan sebagai acuan jawaban dari hipotesis dalam penelitian ini.

\section{Pembahasan Deskriptif}

Bauran yang tepat dalam mengembangkan promosi untuk kegiatan mempromosikan suatu produk sangatkan penting diperhatikan karena bauran promosi ini memiliki pengaruh signifikan kepada pembelian produk yang ditawarkan. Bauran promosi yang tepat dipilih untuk karakteristik pasar yang dijaddikan sebagai target haruslah sesuai. Jika pemilihan bauran promosinya tidak tepat guna, maka yang terjadi ialah informasi mengenai produk tidak tersampaikan dengan baik dan akan mengakibatkan proses penjualan produknya pun akan terganggu. Dengan persaingan yang ketat di bisnis hotel berbintang tiga yang ada di Kota Palembang, maka dibutuhkan strategi promosi yang baik terutama untuk bagaimana memilih bauran promosi yang sesuai agar kelangsungan bisnis tetap berjalan. Dengan kata lain, hal ini sejalan dengan hasil dari penelitian ini yang juga menyatakan bahwa faktor promosi berpengaruh secara signifikan terhadap faktor keputusan pembelian.

Faktor harga adalah salah satu faktor yang menjadikan bahan pertimbangan di setiap konsumen menentukan pembelian pada produknya. Harga yang menempel dalam suatu produk akan memberikan pengaruh dalam konsumen melakukan pembelian suatu produk. Berdasarkan analisis faktor harga disini, dapat dilihat bahwa faktor harga berdasarkan penelitian ini memiliki hubungan tidak langsung terhadap keputusan pembelian. Hal ini terjadi akibat dari adanya faktor lain yang mengikuti yaitu adanya penyelenggaraan event tertentu yang mengakibatkan harga berapa pun yang ditawarkan untuk produk kamar hotel berbintang tiga di Kota Palembang akan laku terjual. Hal ini dikarenakan adanya peningkatan permintaan dari pasar yang dimana peluang ini ditangkap oleh pebisnis untuk menaikkan 
keuntungan mereka dengan cara menaikkan harga kamar. Tetapi salah satu faktor harga yang berpengaruh yaitu pembedaan atau diskriminasi harga berdasarkan pasar tertentu.

Hal ini terjadi karena hotel yang memiliki hubungan tertentu dengan pasar tertentu dan hotel memberikan harga spesial terhadap mereka. Dengan kata lain, diskriminasi harga disini diberikan secara ekslusif kepada pasar tertentu untuk dapat digunakan dalam mereka melakukan pembelian. Atas dasar pemberian harga yang spesial itulah, untuk para klasifikasi hotel tertentu dapat melakukan proses keputusan pembelian terhadap suatu hotel, khusunya di hotel berbintang 3 yang ada di Kota Palembang.

\section{Pembahasan Verifikatif}

Variabel promosi kepada keputusan pembelian memiliki nilai korelasi paling besar dalam hubungan kausalitasnya, sedangkan hubungan kausal antara variabel harga dengan keputusan pembelian memiliki nilai korelasi paling rendah. Hal ini terjadi akibat adanya faktor lain yang juga memberikan pengaruhnya misalkan adanya penyelenggaraan event yang dalam hal ini Kota Palembang menjadi tuan rumah penyelenggaraan Event Internasional Asian Games 2018. Dengan kata lain, adanya event dapat dijadikan salah satu faktor pendorong dalam variabel harga serta melalui kegiatan promosi sebagai variabel promosi sejalan dengan besarnya nilai korelasi terhadap keputusan pembelian.

Hasil penelitian menyimpulkan bahwa promosi dan harga secara simultan berpengaruh terhadap keputusan pembelian di Hotel Bintang tiga Kota Palembang, sedangkan secara parsial peneliti mendapatkan hasil nilai untuk pengaruh langsung tertinggi terdapat pada variabel promosi dan terendahnya terdapat pada variabel harga terhadap tahapan keputusan pembelian.

Melalui perhitungan pengaruh promosi dan harga terhadap proses keputusan pembelian secara keseluruhan diperoleh nilai pengaruh sebesar 99,5\% sedangkan sisanya sebesar 0,5\% dipengaruhi variabel lain yang tidak diteliti dalam penelitian atau variabel epsilon. Berdasarkan hasil penelitian tersebut, dapat disimpulkan bahwa kedua faktor yaitu promosi dan harga merupakan faktor signifikan yang mempengaruhi proses keputusan pembelian dalam industri perhotelan..

\section{KESIMPULAN}

Kesimpulan yang dapat diperoleh dari hasil penelitian mencakup:

1. Sampel penelitian yaitu tamu yang menginap di hotel berbintang tiga di kota Palembang menunjukkan respon tinggi berdasarkan average skor 3,67 untuk variabel promosi, 3,55 untuk variabel harga, dan sebesar 3,69 untuk variabel keputusan pembelian.

Hubungan antara variabel promosi kepada variabel dependen keputusan pembelian dinilai sangat besar dengan jumlah nilai 0,988 melalui pengujian hipotesis secara simultan ataupun parsial dihasilkan bahwa variabel tersebut memiliki pengaruh besar terhadap variabel dependennya.

Hubungan antara variabel harga terhadap variabel dependen dikatakan cukup kuat walaupun nilai korelasinya lebih rendah jika dibandingkan dengan promosi dengan sejumlah besaran nilai harga 0,756 . Dari pengujian hipotesis yang secara simultan maupun secara partial dapat dinyatakan bahwa variabel harga menunjukan pengaruh cukup signifikan kepada variabel proses keputusan pembelian.

2. Kegiatan promosi yang digunakan didalam hotel berbintang tiga di kota Palembang secara umum berjalan dengan efektif. Faktor harga juga mempengaruhi proses keputusan konsumen. Walaupun pengaruh yang diberikan oleh faktor harga ini tidak secara langsung terhadap keputusan pembelian, tetapi faktor harga dapat dijadikan bahan pertimbangan dalam membuat sebuah pemilihan hotel.

3. Hubungan antara promosi dan harga terhadap keputusan pembelian berdasarkan hasil penelitian menyatakan memiliki pengaruh signifikan kepada keputusan pembelian.

Saran yang dapat diberikan terkait kesimpulan hasil penelitian, antara lain:

1. Penentuan strategi promosi menyesuaikan kondisi dan perencanaan pemasaran secara komprehensif agar promosi yang dilakukan dapat berjalan dengan efektif.

2. Mega sports event Asian Games berdampak secara langsung dalam meningkatnya kegiatan pembelian kamar di Palembang, dengan kata lain pemerintah daerah Palembang dapat menyelenggarakan lebih banyak event yang dapat mendatangkan massa dalam jumlah besar atau 
berskala internasional maupun nasional secara berkelanjutan dan penyelenggaraan event adalah salah satu bagian dari kegiatan promosi.

\section{DAFTAR PUSTAKA}

Abdullah Thamrin dan Francis Tantri. 2012. Manajemen Pemasaran. Depok: Rajagrafindo Persada.

Alma, Buchari. 2000. Manajemen Pemasaran dan Pemasaran Jasa. Bandung: Alfabeta.

Cravens, David W and Nigel. F Piercy. 2003. Strategic Marketing. Seventh Edition. New York: Mc Graw-Hill.

Devina, Priska \& Andreani, Fransisca. (2006). Pengaruh Marketing Mix Terhadap Keputusan Pembelian di Susan Span and Resort Bandungan. Jurnal Teknik Elektro. Maret. Vol. 6. No. 1. 108-120.

Gitosudarmo, I. 2000. Manajemen Pemasaran, Edisi Pertama, Cetakan Keenam. Yogyakarta: Penerbit BPFE.

Indriantoro, Nur dan Supomo, Bambang. (2002). Metodologi Penelitian Bisnis Untuk Akuntansi Dan Manajemen. Yogyakarta: BPFE-Yogyakarta.

Kartini, Widyarini F.2014. Variabel Yang Mempengaruhi Keputusan Pemilihan Hotel Syariah. Jumal Ekonomi dan Bisnis Islam. Vol.9, No. 1 ISSN:19079109.

Kotler, Philip Armstrong. 2008. Prinsip-Prinsip Pemasaran, Edisi 12, Jilid I. Jakarta: Penerbit Erlangga.

Kotler, K.L. Keller. 2009, Marketing Manajemen, Jilid I. Edisi Ketigabelas. Erlangga. Jakarta.

K, Nasar K dan K, Manoj P. (2015). Purchase Decision for Apartements: A Closer Look Into The Major Influencing Factors. International Journal of Research In Applied Natural and Social Sciences. May. Vol. 3, No. 5. ISSN: 2347-4580.

Lempoy, Christian N., dkk. 2015. Pengaruh Harga, Lokasi, dan Fasilitas Terhadap Keputusan Menggunakan Jasa Taman Wisata Toar Lumimuut (Taman Eman) Sonder. Jurnal EMBA. Maret. Vol. 3. No. 1 ISSN: 2303-1174.

Lovelock, C., dan Wright, L. 2004. Manajemen Pemasaran Jasa. Jakarta: PT. Intermasa.

Noor, Juliansah. 2011. Metodologi Penelitian.Jakarta: Kencana Prenada Media Group.

Karo, P. K., Iqbal, M., \& Fitriansyah, Y. D. (2019, December). Analysis of Satellite City Readiness Effect towards Organization of Sport Events in South Sumatra Province. In 1st International Conference One Belt, One Road, One Tourism (ICOBOROT 2018). Atlantis Press.

Karo, P. K. (2020). Analisis Pengaruh Experiential Marketing Terhadap Tingkat Kepuasan Peserta Sports Event Jakabaring Wonderful Run Palembang. Pusaka: Journal of Tourism, Hospitality, Travel and Business Event, 2(2), 127-135.

Rizal Putra Amanda dan Sendhang Nurseto. 2018. Pengaruh Harga dan Promosi Terhadap Keputusan Pembelian Mobil Wuling di Semarang

Silalahi, Ulber. 2009. Metode Penelitian Sosial. Bandung: PT. Refika Aditama.

Sudjana. 2009. Metode Statistika. Bandung: Tarsito. 
Sugiyono. 2013. Metodologi Penelitian. Bandung: Alfabeta.

Swastha, Basu. 2007. Azas-Azas Marketing. Yogyakarta: Penerbit Liberty Yogyakarta.

Tjiptono, Fandy. 2014. Pemasaran Jasa. Yogyakarta: Penerbit Andi.

Umar, Husein. 2003. Metode Penelitian Untuk Skripsi dan Tesis Bisnis. Gramedia Pustaka Utama.

Yusanto, Muhammad I. dan Widjajakusuma, Muhammad K. 2002. Menggagas Bisnis Islam. Jakarta: Gema Insani. 